\title{
Analysis of the mechanisms of slope failures triggered by the 2007 Chuetsu Oki Earthquake
}

\author{
Ivan B. Gratchev ${ }^{1}$ and Ikuo Towhata ${ }^{2}$
}

1) Lecturer, Griffith School of Engineering, Griffith University, Gold Coast, Australia; email: ivangratchev@gmail.com

2) Professor, Department of Civil Engineering, University of Tokyo, Japan. 


\section{Abstract.}

The 2007 Chuetsu Oki earthquake $\left(\mathrm{M}_{\mathrm{JMA}}=6.6\right)$ triggered more than one hundred slope failures in the northwest part of Niigata prefecture, Japan. A reconnaissance survey conducted by the authors revealed that although most of the failures were only a few meters deep, they still caused significant damage to roads, railways, and houses. It was also found that a vast number of shallow slides were concentrated along the coastal line of the Japan Sea, while only few, but relatively larger failures occurred in a mountainous part of the study area, which is located in a considerable distance from the earthquake's epicenter. This paper summarizes the reconnaissance observations, describes the geologic characteristics of the area covered by landslides, provides characterization of major types of the landslides, and examines the causes and mechanisms of typical failures. In addition, this paper seeks to investigate the mechanism of the Ohzumi landslide, the largest slide triggered by the Chuetsu Oki earthquake. For this purpose, a comprehensive analysis that included field investigation and laboratory testing of soils samples was performed. Results of field investigation suggested that the failure plane of the Ohzumi landslide formed in a saturated layer of sandy soil near a boundary with bedrock. Data from undrained cyclic loading triaxial compression tests indicated that the sandy material was highly susceptible to generation of high excess pore-water pressures during earthquake loading. On the basis of the obtained results and the outcome of seismic response and slope stability analyses, the authors posited an explanation on the mechanism of the Ohzumi landslide.

Keywords: liquefaction, landslide, earthquake, mechanism, cyclic tests 


\section{Introduction}

The Chuetsu Oki earthquake of July 16, 2007 triggered more than one hundred landslides in the northwest part of Chuetsu region of Niigata Prefecture, Japan. Toyota and Onoue (2008) and Hasegawa et al. (2008) reported that this natural disaster had a significant impact on the infrastructure of the Chuetsu region as the seismically-induced landslides damaged roads, blocked railways and destroyed houses. A few days after the earthquake occurred, a research group from the University of Tokyo, Japan conducted a reconnaissance survey to assess the damage caused by landslides. The survey revealed that the majority of slope failures were shallow, highly disrupted slides, which were concentrated along the coastline between Kashiwazaki City and Nishiyama town (Fig. 1). However, it is interesting to note that the largest slide named the Ohzumi landslide was observed in a mountainous part of the area, relatively far from the earthquake's epicenter. This paper reports and discusses field observations regarding the landslides, describes the conditions in the area that contributed to slope instability, provides characterization of the major types of landslides, and examines the basic causes of the typical slope failures. In addition, the mechanism of the Ohzumi landslide is studied in detail to determine the major causes of this "anomalous" slide.

\section{Previous works}

Earthquake-triggered landslides have been a challenging topic for both researchers and geotechnical engineers as can be seen in the literature of the past few decades. As the prediction of such phenomena is difficult, this type of disaster has long been associated with great destruction and human loss. In recent history, there have been several examples of catastrophic landslides caused by earthquakes such as the Chi-Chi earthquake in Taiwan (Wang et al., 2003), the 1989 Loma Prieta earthquake (Keefer 1998), the 1994 Northridge earthquake (Harp and Jibson, 1996) in California, USA, the 1995 Hygoken-Nanbu earthquake (Sassa et al. 1996), and the 2004 Chuetsu earthquake (Kieffer et al. 2006, Chigira and Yagi, 2005) in Japan.

In the past few decades, a number of studies have been carried out to establish general relationships between the distribution of landslides and several important factors such as earthquake magnitude (Keefer, 1984; Khazai and Sitar, 2003), geomorphologic features 
(Parise and Jibson, 2000), and geologic characteristics (Chigira and Yagi, 2005) of the earthquake-struck areas. Also, a fair amount of research has been conducted to understand the mechanisms of the Turnagain Heights landslide in Alaska, USA (Seed and Wilson, 1967), the Tsaoling landslide in Taiwan (Chigira et al. 2003), and the HigashiTakezawa landslide in Japan (Sassa et al. 2005). However, these works have mostly focused on the characteristics of extremely large landslides, which are considered to be the rarer phenomenon. In fact, statistics of recent disasters indicate that shallow slides were the most common type of slope failures during the 1999 Chi-Chi earthquake (Khazai and Sitar, 2003), the Northridge earthquake (Parise and Jibson, 2000), and the 2004 Chuetsu earthquake (Chigira and Yagi, 2005). Despite their relatively smaller size, these slides still cause considerable economic damage by blocking roads and rail tracks and destroying houses. For example, Koseki et al. (2006) reported that several major highways and prefectural roads suffered from significant damage and were closed at 101 sites mostly due to shallow slides following the 2004 Mid-Niigata Prefecture earthquake, Japan. Clearly, a better understanding of the main causes and mechanisms of shallow landslides is essential to developing more effective preventive measures, and thus decreasing the degree of damage.

This study endeavors to contribute to the understanding of the mechanisms of shallow landslides, and seeks to clarify the effects of different factors on the occurrence of this phenomenon. The Chuetsu area of Niigata Prefecture, Japan, which experienced a number of shallow failures following the Chuetsu Oki earthquake in 2007, was selected for this purpose.

\section{The Chuetsu Oki earthquake}

The Chuetsu-Oki earthquake $\left(\mathrm{M}_{\mathrm{JMA}}=6.6\right)$ struck the northwest part of Niigata Prefecture, Japan on July 16, 2007. Its epicenter was located on a continental shelf of the Japan Sea (Fig. 1) about $20 \mathrm{~km}$ northwest of Kashiwazaki, where the highest ground acceleration of 813 gal was recorded (K-Net 2008). Following the earthquake, more than one hundred landslides occurred (Toyota and Onoue, 2008; Hasegawa et al. 2008), causing considerable damage to engineering structures such as roads and rail tracks (Fig. 2). The area affected by the earthquake was located in the northern part of Kashiwazaki city, 
including the Nishiyama town and the Kashiwazaki-Kariwa nuclear power plant, which was partly damaged by the earthquake.

\section{Local geologic conditions}

Geologic characteristics of the area covered by landslides are shown in Fig. 3. According to Kobayashi et al. (1995), the southern part is mainly comprised of mudstone and volcanic conglomerate of the Yoneyama formation (Fig. 3). The central part, including the Kashiwazaki port and some area around the Kashiwazaki-Kariwa nuclear power plant, primarily consists of sand deposits of the Arahama Dune Bed. Massive sandstone and siltstone of the late Pliocene Nishiyama Formation are distributed in the northern parts of the study area. The bedrock is blanketed locally by colluvium, and unconsolidated Pleistocene to Holocene alluvial deposits are present within river and stream channels and their floodplains (Fig. 3).

\section{Mechanisms of shallow landslides}

Field observations revealed that most of the triggered landslides were only a few meters deep and involved slope-parallel failures of colluvium and highly weathered bedrock on steep slopes (55-60 degrees). A few slides that had a width of $10 \mathrm{~m}$ and an estimated average thickness of 2-3 $\mathrm{m}$ occurred in Shiiya, a place where the sliding mass blocked the national road No. 352. (Fig. 2, Photo A). The slip surfaces of these failures developed along the boundary with more intact and less weathered mudstone of Shiiya Formation. In the south part of the studied area, several slope failures of a similar type were found in the zone of weathered mudstone of Yoneyama Formation. The Oumigawa landslide was the largest landslide of those, with a size of $40 \mathrm{~m}$ in width, $50 \mathrm{~m}$ in length, and 3-4 $\mathrm{m}$ in depth. It blocked the railroad near JR Oumigawa station of the Shinetsu Line, suspending the train service for one month (Fig. 2, Photo B). Several smaller landslides were also observed to the north and south of that location. Onoue and Toyota (2008) reported a few shallow failures, mostly lateral spreading, in deposits of the Arahama dune. Sand boils which resulted from liquefaction were observed by the authors in the Kashiwazaki port area, where the earthquake caused some damage to engineering structures. 
It is interesting to note that only a few slides were triggered in the mountainous area, relatively far from the epicenter. The Ohzumi landslide, the largest slide triggered by the earthquake, was one of those (Fig. 2, Photo C). It occurred on a relatively gentle slope with an inclination of about 25 degrees in deposits of the Uonuma Formation. The landslide mass moved downward with a piece of National Highway 8, temporarily blocking the Kuro River. The size of the slide was estimated to be about $125 \mathrm{~m}$ in width and $100 \mathrm{~m}$ in length, and the thickness of the sliding mass varied in the range of 6-7 meters. As a part of the emergency measures, the unstable part of the slope was quickly removed, and the road was re-opened after a week.

In summary, there were two major types of slope failures triggered by the 2007 Chuetsu Oki earthquake. The first type is shallow disrupted slides that occurred in colluvuim and highly weathered mudstone along the coast line. The other can be described as relatively larger slides that involved sandy material. The Oumigawa landslide and the Ohzumi landslide, respectively, seem to be the representative examples of each type.

To shed light on the mechanisms of the first type of failure, Toyota and Onoue (2008), Gratchev and Towhata (2008) studied the geotechnical properties of highly weathered mudstone collected from the sliding surface of the Oumigawa landslide. The results from undrained cyclic loading triaxial compression tests indicated that the soil had small potential for generation of high excess pore-water pressures, and the earthquake loading would only slightly decrease the soil's strength. On the basis of field and laboratory investigation, Gratchev and Towhata (2008) hypothesized that the Oumigawa landslide occurred due to a combination of two factors: 1) large initial shear stresses originated from the high slope inclination and 2) permanent displacements of large magnitudes developed in the soil during the earthquake loading.

The mechanism of the second type is discussed in this paper, using the results of a comprehensive study of the Ohzumi landslide. Field data were first utilized to clarify the geologic characteristics of the landslide site. Results of laboratory examination of soil samples combined with the outcome of seismic response analysis were then used to estimate the stability of the slope prior to and after the earthquake. Finally, on the basis of the obtained results, an attempt was made to explain the mechanism of the failure. 


\section{Analysis of the mechanism of the Ohzumi landslide}

\subsection{Field data concerning the Ohzumi landslide}

A borehole drilling program, including standard penetration tests (SPT), was conducted by the local authorities shortly after the landslide occurred to clarify the geology of the area and to evaluate the in-situ properties of soils, thus providing a basis for reconstruction work. Utilizing the obtained results, a cross-section of the slope before and after the failure was reconstructed as shown in Fig. 4. According to the borehole data, the failure plane formed in colluvial sandy soils above the boundary with siltstone. Results of SPT tests conducted at BV-3 (Figs. 4 a,b) yielded relatively small N-values $(<10)$ at the depth range of 2-5 meters. The SPT-test data also suggested that the failure was triggered in sandy material, whose value of SPT blow counts was about 17. Furthermore, ground water was reported in the boreholes $\mathrm{BV}-1$ and $\mathrm{BV}-3$, a finding that supports the assumption that the sand layer immediately above the boundary with the bed rock was saturated prior to the earthquake. However, due to the fact that no ground water was found in the borehole BV-2 (Fig. 4a), it is not clear whether the ground water table existed above the failure plane or the water in the landslide mass was distributed sporadically.

It is interesting to note that similar geologic conditions were cited as one of the main factors that caused the instability of numerous slopes during the 2004 Mid-Niigata Chuetsu earthquake (Chigira and Yagi, 2005). Sassa et al. (2005) and Gratchev et al. (2006) studied the dynamic properties of sandy soils from several large-scale landslides triggered by the 2004 Mid-Niigata Chuetsu earthquake, and noted that liquefaction of loose sand significantly contributed to the slope failures.

\subsection{Laboratory examination of the soil from the Ohzumi landslide}

\subsubsection{Tested soils}

A series of laboratory tests, including grain size distribution and triaxial compression tests, were conducted to determine the properties of the soil collected from the failure plane. Results of grain-size distribution analysis presented in Fig. 5 indicate that the soil 
was mostly sand with about $10 \%$ fines. The specific gravity of the sand was determined to be 2.69 , and its minimum and maximum void ratios were 0.641 and 1.030 , respectively.

\subsubsection{Triaxial Compression Tests}

A series of consolidated-drained tests were carried out to determine the strength characteristics of the soil, and thus provide data for use in stability analysis. All specimens were produced by the air-pluviation method (JGS 0520-2000). The initial height and diameter of the test specimens prior to saturation were 75 and $150 \mathrm{~mm}$, respectively. Saturation was performed by purging the dry specimen with carbon dioxide for approximately one hour. Deaired water was then introduced into the specimen from the bottom drain line. A minimum B-value of 0.97 was obtained for all tests. After saturation, the specimens were isotropically consolidated to different effective minor principal stresses, $\sigma_{3}{ }_{3}$, ranging from 30 to $100 \mathrm{kPa}$. The triaxial compression tests were performed in accordance with the Japanese Geotechnical Standard (JGS 0524-2000) with the failure criterion defined as $15 \%$ axial strain.

The test data are presented in Fig. 6 in terms of principal stress difference (deviator stress, $\mathrm{q}=\sigma_{1}-\sigma_{3}$ ) against axial strain (a), and volumetric strain relationship (b). The effective stress conditions at failure for this series of tests are plotted in Fig. 6c in the form of half the principal stress difference, $\left(=\left(\sigma^{\prime}{ }_{1}-\sigma^{\prime}{ }_{3}\right) / 2\right)$ versus half the sum of the major and minor principal stresses $\left(=\left(\sigma_{1}{ }^{\prime}+\sigma_{3}{ }^{\prime}\right) / 2\right)$. From this graph the strength parameters of the sand were determined as follows: $\phi^{\prime} \approx 38.8^{\circ}$ and $\mathrm{c}^{\prime} \approx 5 \mathrm{kPa}$.

\subsection{Stability of the slope before the earthquake}

A slope stability analysis for the conditions existing before the earthquake was carried out by means of the finite element method (FEM). The main principles of a finite element approach to slope stability analysis are discussed in detail by Griffiths and Lane (1999), who noted that slope failure in the finite element model occurs "naturally" through the zones in which the shear strength of the soil is insufficient to resist the shear stresses. The factor of safety in such an analysis is computed according to the "shear strength reduction technique" (Matsui and San, 1992). 
The analysis was conducted on the basis of the Mohr-Coulomb failure criterion by means of the FEM computer code GuSLOPE developed at Gunma University, Japan. Table 1 summarizes the characteristics of the soils used in the analysis. Appropriate stress-strain parameters for each soil type were established using the results of consolidated-drained triaxial compression tests (Fig. 6) and published data for similar soils (Kaino et al. 1995, Miura et al. 1995).

Results of the slope stability analysis presented in Fig. 7 suggest that the slope was amply stable before the earthquake as the most critical failure plane yielded a safety factor of 1.34 .

\subsection{Assessment of slope instability during the earthquake}

The procedure for dynamic analysis of slope stability used in this research is somewhat similar to that which was proposed by Seed et al. (1969, 1975a) for saturated cohesionless materials. It involved the following sequence of operations: (1) the initial stresses in the slope acting on the potential failure plane before the earthquake were evaluated; (2) the time history of shear stresses induced by the earthquake were determined and represented by an equivalent number of uniform load cycles $(\mathrm{N})$; (3) cyclic loading triaxial compression tests were performed on samples initially consolidated under the range of confining pressures and consolidation stress ratio conditions to determine the cyclic stresses causing failure in the expected number, N, of stress applications. The peak shear stresses required to cause failure in $\mathrm{N}$ cycles at points along the potential sliding surface were determined and compared with the peak shear stresses induced by the earthquake on the same surface.

\subsubsection{Static analysis}

As a first step in applying this procedure, stresses acting along the failure plane before the earthquake were evaluated by means of the finite element procedure on the basis of Mohr-Coulomb failure criterion. Of particular importance were the overburden, lateral and shear stresses developed in the layer of saturated sand above the siltstone before the earthquake. Typical values of the initial shear stress $(\tau, \mathrm{kPa})$ are presented in Fig. 8. These data were further utilized to calculate values of major and minor principal stresses, 
$\sigma_{1}$ and $\sigma_{3}$, parameters that were used in the cyclic loading triaxial tests to reproduce the stress conditions existing in the slope before the earthquake. It was found that a primary stress ratio $\mathrm{K}=\sigma_{1} / \sigma_{3}$ at the base of the saturated layer was somewhat equal to 2 , slightly varying along the failure plane.

\subsubsection{Dynamic Analysis}

To determine the stresses induced by the earthquake, the linear equivalent onedimensional site response analysis with strain-dependent modulus and damping was used. By utilizing the soil profile information at the accelerograph site, the ground motion record obtained at Kashiwazaki city by a K-net seismograph (K-net, 2008) was first deconvolved to bed rock motion. Details of the "deconvolution" procedure can be found in Towhata (2008). As the distance between the epicenter and the seismograph was close to that between the epicenter and the Ohzumi landslide, it was assumed that the intensity of bed rock motion at these two points would be similar. Thus the bed rock motion obtained at the seismograph site was utilized to compute the seismic response of the soil at the landslide site at a given depth. Results of such an analysis conducted for the layer of saturated sand at the depth of 4-6 m are presented in Fig. 9. Finally, the seismicallyinduced shear stresses were normalized to the initial effective vertical stress and converted to an equivalent series of uniform cyclic stress applications $(\mathrm{N})$, in accordance with the procedure described by Seed et al. (1975b). According to the Seed-Idriss (1971) simplified procedure for evaluating soil liquefaction potential, the factor of 0.65 should be used to convert the peak cyclic shear stress ratio to a cyclic stress ratio (CSR) that was representative of the most significant cycles over the full duration of loading. For example, following the method described in Seed et al. (1975b), it was found that the irregular earthquake loading at the depth range of 4-6 m shown in Fig. 9 could be represented by five uniform load cycles with a cyclic stress ratio (CSR) of 0.35-0.40.

\subsubsection{Dynamic properties of the soil}

A series of triaxial compression tests were carried out to evaluate the strength and deformation characteristics of saturated specimens of the sand under undrained cyclic loading conditions (JGS 0541-2000). The tests were performed with different cyclic 
stress ratios $(\mathrm{CSR}=0.4 ; 0.3 ; 0.2)$, and the failure criterion was defined as $5 \%$ axial strain, following Ishihara (1996). The results of two representative tests with CSR $=0.4$ and 0.3 conducted on specimens initially consolidated to a principal stress ratio, $\mathrm{K}=2.0$, with an effective minor principal stress of $\sigma_{3}{ }^{\prime}=50 \mathrm{kPa}$, are shown in Fig. 10. The effective stress paths are presented on the $p^{\prime}-q$ diagram, where $p^{\prime}$ is effective mean normal stress, and $\left.p^{\prime}=\left(\sigma^{\prime}{ }_{1}+2 * \sigma^{\prime}{ }_{3}\right) / 3\right)$ is assigned to the horizontal axis and $q\left(=\sigma_{1}-\sigma_{3}\right)$ is plotted on the vertical axis. In the case of $\mathrm{CSR}=0.4$ (Fig. 10a), the specimen quickly reached an axial strain of $5 \%$ in two cycles of loading. As can be seen in Fig. 10b, excess pore-water pressures developed during undrained cyclic loading, leading to a loss in the effective stress. For the stress conditions represented by $\mathrm{CSR}=0.3$, eight cycles of loading were necessary to cause 5\% axial strain and thus trigger failure (Fig. $10 \mathrm{c}, \mathrm{d}$ ).

By using different values of the cyclic deviator stress and noting the number of cycles required to cause failure, the cyclic deviator stress required to cause failure in five cycles could readily be determined by interpolation. From the data presented in Fig. 11 and the results of dynamic response analysis (Fig. 9), it can be inferred that the stresses induced by the earthquake $(\mathrm{CSR}=0.35-0.4)$ would have been sufficient to trigger significant deformation in the sandy layer located beneath the embankment, immediately above the siltstone.

\subsubsection{Assessment of slope stability after earthquake}

To evaluate the post-earthquake stability, slope stability analysis was carried out by means of the finite element procedure. Previous studies (Seed et al. 1969, 1975; Lee and Roth 1977) indicate that the governing parameters for such an analysis are the static shear stresses acting on the failure plane and the post-earthquake static strength of the soil after it has been weakened by seismic shaking. The post-earthquake strength of the sand was determined from the undrained cyclic tests as schematically shown in Fig. 12. In this figure, the stress conditions existing before the application of cyclic loading are described by A, a point where the total stress is equal to the initial effective stress. During cyclic loading, excess pore-water pressures built up, resulting in a significant decrease in the effective stress. At the end of cyclic loading, point B, the maximum available effective strength of the sand would be determined by the Mohr-Coulomb envelope previously 
deduced from the triaxial compression tests (Fig. 6c). Thus, the strength described by the point $\mathrm{C}$ can be considered as the post-earthquake strength of the sand. Assuming that cohesion of the liquefied sand is close to zero, the strength of soil is then normalized to the initial effective vertical stress, yielding a liquefied strength ratio described by the friction angle $\phi_{\mathrm{ae}}$. Following this procedure, the post-earthquake strength of the tested soil can be derived from the laboratory data presented in Fig. 10. It was found that the friction angle of the liquefied sandy material from the Ohzumi landslide is approximately $14^{\circ}$. It is noted that this value falls within the range of $13-17^{\circ}$, the range of friction angles that is typical for liquefied sands, according to numerous case studies (de Alba et al. 1987, Ishihara et al. 1990, 1993, Stark and Mesri 1992, and Olson and Stark 2003).

The results of slope stability analysis presented in Fig. 13 showed the most critical failure plane that formed in the sand deposit above the boundary with the siltstone. The location of the plane seems to be in a reasonably good agreement with the position of the sliding surface deduced from the field investigation (Fig. 4a). The computed safety factor of 0.58 indicated that the earthquake loading significantly undermined the stability of the slope. Thus, on the basis of the obtained data, it can be hypothesized that during the earthquake, high pore-water pressures generated in the layer of saturated sand, leading to a decrease in the shear strength, resulting in slope instability.

\subsubsection{Post-earthquake liquefaction evaluation}

The liquefaction evaluation of the landslide mass was performed to determine the stability of the slope in the event of future earthquakes with a similar magnitude. The liquefaction potential of soil was estimated on the basis of SPT data, following the standard procedure developed by the Japan Road Association (1996). This procedure yields a safety factor against liquefaction $\left(\mathrm{F}_{\mathrm{L}}\right)$, a parameter that is defined as the ratio between the liquefaction resistance of soil and the cyclic stress ratios induced by earthquake ground motions. The liquefaction resistance of soils is computed on the basis of SPT blow counts which are normalized with respect to the content of fine particles. The cyclic stress ratio is estimated on the basis of earthquake ground motion data in a manner similar to the "simplified procedure" developed by Seed and Idriss (1971). The 
interested reader is referred to Nagase et al. (2006), where a detailed explanation of the procedure is given and its application to case histories is described.

The results of the liquefaction triggering assessment obtained for the borehole BV-3 are plotted in Fig. $4 c$ as the variation of $F_{L}$ with depth. As can be seen in this figure, some portions of the sandy layer between depths of 2 and $6 \mathrm{~m}$ can still be considered potentially liquefiable as the safety factor against liquefaction was estimated to be less than one. This indicates that the sand immediately adjacent to the boundary with siltstone remains in a contractive state, that is, susceptible to undrained strain-softening behavior.

\section{Discussion}

The large number of shallow landslides triggered by the 2007 Chuetsu Oki earthquake presents a rare opportunity for researchers to study the mechanisms of such failures. Field observations and landslide distribution analysis indicate that geologic conditions and steep local topography had a significant influence on the formation of numerous slides in the coastal area. It should be noted here that these two important factors have long been recognized as the major causes of seismically-induced landslides, and as a result, often evaluated during landslide hazard assessment. Yet, geology and topography alone fail to explain the mechanism of the Ohzumi landslide. A detailed study of this failure described in the preceding pages indicates the important role of site conditions, including groundwater and soil characteristics, in the occurrence of seismically-induced landslides. Results of field and laboratory investigation suggested that the presence of a layer of loose sand at the boundary with bedrock was one of the main causes of slope instability. Unfortunately, landslide studies often do not give sufficient consideration to the influence of site conditions, especially those that involve large areas, as doing so would thus require detailed site investigation.

Clearly, a better understanding of the basic causes and mechanisms of landslides may significantly improve our ability to identify landslide-prone areas. A simple case study such as the one presented in this paper can be useful for pinpointing areas with high

potential for landslides. Compared to more elaborate methods that analyze the progressive development of failure but which require more detailed studies as well as more sophisticated software, this technique mainly utilizes the results of field and 
laboratory investigation. As it is less time-consuming, it can be performed by a geotechnical engineer within a reasonable time frame to detect areas with high potential for the occurrence of landslides. However, the authors also recognize that some degree of judgment needs to be exercised by an engineer as the available information such as the location of potential failure plane or in-situ characteristics of soil may be interpreted differently by other investigators.

\section{Summary}

This paper describes the geological and geotechnical characteristics of seismicallyinduced landslides triggered by the 2007 Chuetsu-Oki earthquake. Two types of slope failures were identified and their mechanisms were discussed. The first type commonly found along the shore consists of relatively shallow slides (1-2 $\mathrm{m}$ deep) that occurred primarily on steep slopes comprised of colluvium and weathered bedrock. The second type includes relatively larger slides with slip planes formed in sandy material.

The mechanism of the Ohzumi landslide, the largest slide triggered by the quake, was examined in detail in order to clarify the effects of geological settings, hydrological conditions as well as the geotechnical properties of soils on the occurrence of seismicallyinduced landslides. On the basis of the field and laboratory data, the following conclusions can be drawn:

- Unlike the numerous coastal landslides that occurred in highly weathered mudstone, the failure plane of the Ohzumi landslide formed in the layer of saturated sand immediately adjacent to the boundary with siltstone;

- During the earthquake the slope was likely subjected to a series of cycles of earthquakeinduced inertia forces which might be represented by 5 uniform force cycles with a CSR of 0.35-0.4.

- Comparisons of the earthquake-induced stresses that acted on the failure plane with the cyclic resistance of the sand suggested that high excess pore-water pressures could have generated in the layer of saturated sand near the boundary with siltstone.

- Slope stability analysis conducted using the post-earthquake strength of the soil yielded a low value $(0.58)$ of the safety factor, indicating that the stability was significantly undermined by the earthquake loading. 


\section{Acknowledgements}

The authors would like to thank Mr. Akira Ezoe, a researcher from the University of Tokyo, for his significant help throughout this investigation. Special acknowledgement should be given to Professor Keizo Ugai and Assistant Professor Dr. Cai Fei from Gunma University for their kind permission to use computer code GUSLOPE for this research. SPT data were kindly provided by the local authorities. The financial support was provided by the Japan Society for the Promotion of Science (JSPS).

\section{References}

Chigira, M., Wang, W., Furuya, T., Kamai, T., 2003. Geological causes and geomorphological precursors of theTsaoling landslide triggered by the 1999 Chi-Chi Earthquake, Taiwan. Engineering Geology 68, 259-273.

Chigira, M., Yagi, H., 2005. Geological and geomorphological characteristics of landslides triggered by the 2004 Mid Niigata prefecture earthquake in Japan. Engineering Geology 82, 202-221.

De Alba, P., Seed, H., Retamal, E., Seed, R., 1987. Residual strength of sand from dam failures in the Chilean earthquake of March 3, 1985. EERC Report N. UCB/EERC-8711, University of California, Berkeley, CA.

Gratchev, I., Sassa, K., Osipov, V., Sokolov, V., 2006. The liquefaction of clayey soils under cyclic loading. Eng Geol 86, 70-84.

Gratchev, I., Towhata, I., 2008. Analysis of a slope failure triggered by the 2007 Chuetsu Oki Earthquake. Proceedings of First World Landslide Forum, Tokyo, 227-230.

Griffiths, D., Lane, P., 1999. Slope stability analysis by finite elements. Geotechnique 49 (3), 387-403.

Harp, E.L., Jibson, R.W., 1996. Landslides triggered by the 1994 Northridge, California earthquake. Bulletin of the Seismological Society of America, 86 (1B): S319-S332.

Hasegawa, S., Dahal, R., Nishimura, T., Nonomura, A., Yamanaka, M., 2008. DEMBased Analysis of Earthquake-Induced Shallow Landslide Susceptibility. Geotech Geol Eng, 27: 419-430. 
Ishihara, K., Yasuda, S., Yoshida, Y., 1990. Liquefaction-induced flow failure of embankments and residual strength of silty sands. Soils and Foundations 30 (3), 69-80.

Ishihara, K., 1993. Liquefaction and flow failure during earthquakes. Geotechnique 43 (3), 351-415.

Ishihara, K., 1996. Soil behaviour in earthquake geotechnics. Clarendon press, Oxford.

JGS 0520-2000, 2000. Preparation of Soil Specimens for Triaxial Tests. The Japanese Geotechnical Society.

JGS 0524-2000, 2000. Method for Consolidated-Drained Triaxial Compression Test on Soils. The Japanese Geotechnical Society.

JGS 0541-2000, 2000. Method for cyclic undrained triaxial test on soils. The Japanese Geotechnical Society.

Kaino, T., Masuda, T., Mizumoto, K., 1995. A case study of comparison between static and dynamic analyses for seismic slope stability. Proceedings of IS-Tokyo 95, Earthquake Geotechnical Engineering, Tokyo, 1043-1048.

Keefer, D., 1984. Landslides caused by earthquakes. Geological Society of America Bulletin 95, 406-421.

Keefer, D.K., ed., 1998. The Loma Prieta, California, earthquake of October 17, 1989Landslides. U.S. Geological Survey Professional Paper 1551-C, 185 p., 5 pl.

Keefer, D.V., 2000. Statistical analysis of an earthquake-induced landslide distribution the 1989 Loma Prieta, California event. Engineering Geology 58, 231- 249.

Kieffer, D.S., Jibson, R., Rathje, E.M., Kelson, K., 2006. Landslides triggered by the 2004 Niigata Ken Chuetsu, Japan, earthquake. Earthquake Spectra 22: S47-S73.

Khazai B, Sitar N (2003) Evaluation of factors controlling earthquake-induced landslides caused by Chi-Chi earthquake and comparison with the Northridge and Loma Prieta events. Eng Geol 71:79-95.

K-Net, 2008. Strong tremor by the Niigata Chuetsu-oki Earthquake, 2007 June 16. http://www.k-net.bosai.go.jp/k-net/topics/chuetsuoki20070716/chuetsuoki_1.htm.

Kobayashi I, Tateishi M, Yoshimura T, Ueda T, Kato H. 1995. Geol Map Jpn 1:50000. Kashiwazaki, Geological Survey of Japan 
Koseki, J., Sasaki, T., Wada, N., Hida, J., Endo, M., Tsutsumi, Y., 2006. Damage to earth structures for national highways by the 2004 Niigata-ken Chuetsu earthquake. Soils and Foundations 46 (6), 739-750.

Lee, K., Roth, W., 1977. Seismic stability analysis of Hawkins Hydraulic fill dam. Journal of the Geotechnical Engineering Division, ASCE, 103 (6), 627-644.

Matsui, T., San, K., 1992. Finite element slope stability analysis by shear strength reduction technique. Soils and Foundations 32 (1), 59-70.

Miura, K., Yoshida, N., Wakamatsu, K., 1995. Damage to fill embankment during the 1993 Kushiro-oki earthquake. Proceedings of IS-Tokyo 95, Earthquake Geotechnical Engineering, Tokyo, 1057-1062.

Nagase, H., Zen, K., Hirooka, A., Yasufuku, N., Kasama, K., Kobayashi, T., Maeda, Y., Uno, K., Hashimura, K., Chen, G., 2006. Zoning for liquefaction and damage to port and harbor facilities and others during the 2005 Fukuoka-Ken Seiho-Oki earthquake. Soils and Foundations 46 (6), 805-816.

Olson, M., Stark, T., 2003. Use of laboratory data to confirm yield and liquefied strength ratio concepts. Canadian Geotechnical Journal, 40, 1164-1184.

Onoue, A., Toyota, H., 2008. Damage induced by the 2007 Niigataken Chuetsu-Oki earthquake. Proceedings of the $14^{\text {th }}$ World Conference on Earthquake Engineering, Beijing, China, on CD.

Parise, M., Jibson, R.W., 2000. A seismic landslide susceptibility rating of geologic units based on analysis of characteristics of landslides triggered by the 17 January, 1994 Northridge, California earthquake. Engineering Geology 58, 251- 270.

Sassa, K., Fukuoka, H., Wang, F., Wang, G., 2005. Dynamic properties of earthquakeinduced large-scale rapid landslides within past landslide masses. Landslides 2 (2), $125-134$.

Seed, H. B., Lee, K. L., Idriss, I.M., 1969. Analysis of Sheffield dam failure. Journal of the Soil Mechanics and Foundation Division, ASCE, 95 (6), 1453-1490.

Seed, H.B., Wilson, S.D., 1967. The Turnagain Heights Landslide, Anchorage, Alaska. Journal of the SMFD, ASCE, Vol. 93, No. SM4, 325-353. 
Seed, H. B., Idriss, I.M., Lee, K.L., 1975a. Dynamic analysis of the slide in the lower San Fernando dam during the earthquake of February 9, 1971.Sheffield dam failure. Journal of the Geotechnical Engineering Division, ASCE, 101 (9), 889-911.

Seed, H.B., Idriss, I.M., Makdisi, F., Banerjee, N., 1975b. Representation of irregular stress time histories by equivalent uniform stress series in liquefaction analyses. Report N. EERC 75-29, California.

Seed, H.B., Idriss, I.M., 1971. Simplified procedure for evaluating soil liquefaction potential, J Soil Mech Found Div, ASCE 97, 1249-1273.

Stark, T., Mesri, G., 1992. Undrained shear strength of liquefied sands for stability analysis. Journal of Geotechnical Engineering, 118 (11), 1727-1747.

Towhata, I., 2008. Geotechnical Earthquake Engineering. Springer.

Toyota, H., Onoue, A., 2008. Characterization of slope failures during the 2004 Niigataken Chuetsu and the 2007 Niigata-ken Chuetsu-Oki earthquake. Proceedings of the $14^{\text {th }}$ World Conference on Earthquake Engineering, Beijing, China, on CD. 
Figure captions.

Table 1. Soil parameters used in the analyses.

\begin{tabular}{|c|c|c|c|c|c|c|c|}
\hline $\begin{array}{c}\text { Name of } \\
\text { soil }\end{array}$ & $\gamma \mathrm{kN} / \mathrm{m}^{3}$ & $\mathrm{E}: \mathrm{kPa}$ & $v$ & $\mathrm{c}^{\prime}: \mathrm{kPa}$ & $\begin{array}{c}\phi^{\prime}: \\
\text { degrees }\end{array}$ & $\mathrm{c}_{\mathrm{ae}}: \mathrm{kPa}$ & $\begin{array}{c}\phi_{\mathrm{ae}}: \\
\text { degrees }\end{array}$ \\
\hline Sand & 16 & 20000 & 0.3 & 5 & 38.8 & 0 & 14.0 \\
\hline Silt & 20 & 70000 & 0.3 & 50 & 45.0 & 50 & 45.0 \\
\hline
\end{tabular}

Note: $\gamma$ - total unit weight, E - Young's modulus, $v$ - Poisson's ratio, c' - effective cohesion, $\phi$ ' friction angle, $c_{\mathrm{ae}}$ : cohesion after the earthquake, and $\phi_{\mathrm{ae}}-$ friction angle after the earthquake.

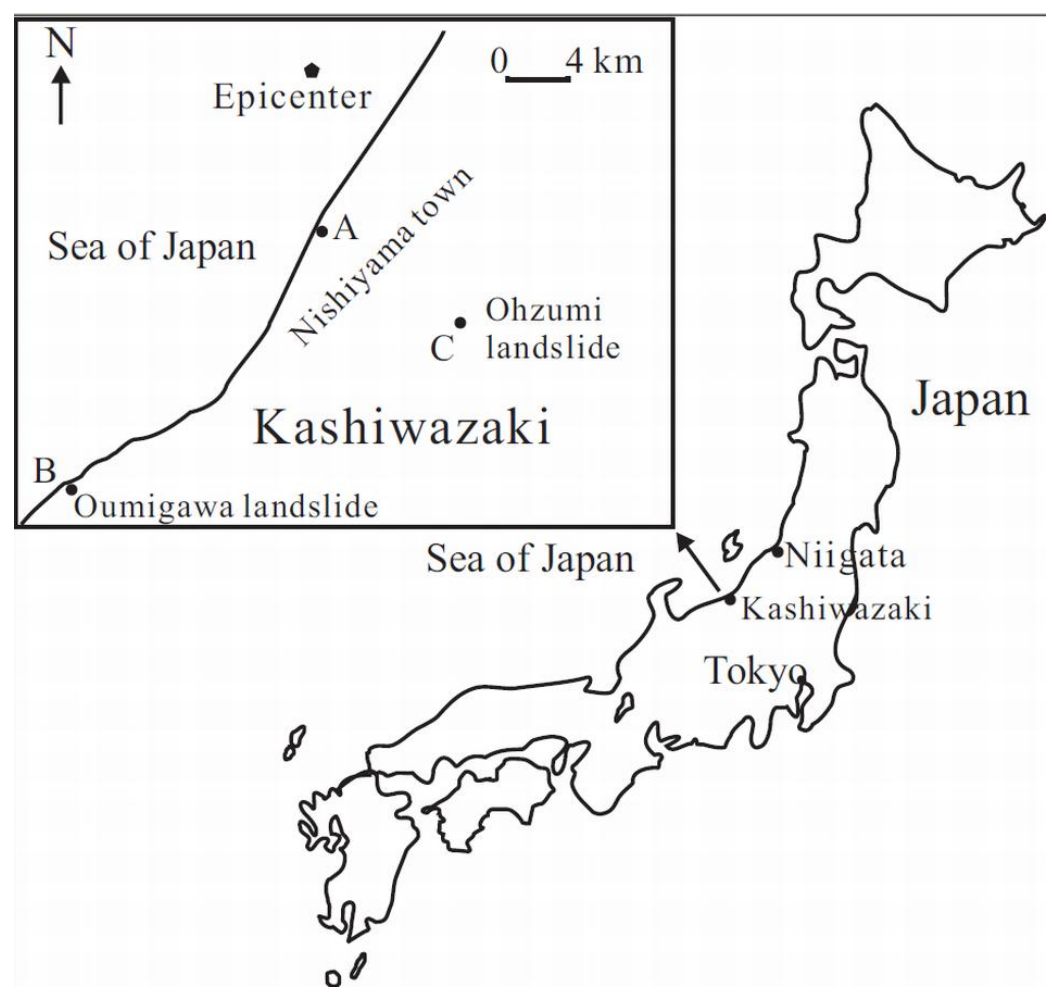

Figure 1. Location of the study area. (A, B, and C denote the locations where the Photos A, B, and $\mathrm{C}$ presented in Figure 2 were taken). 

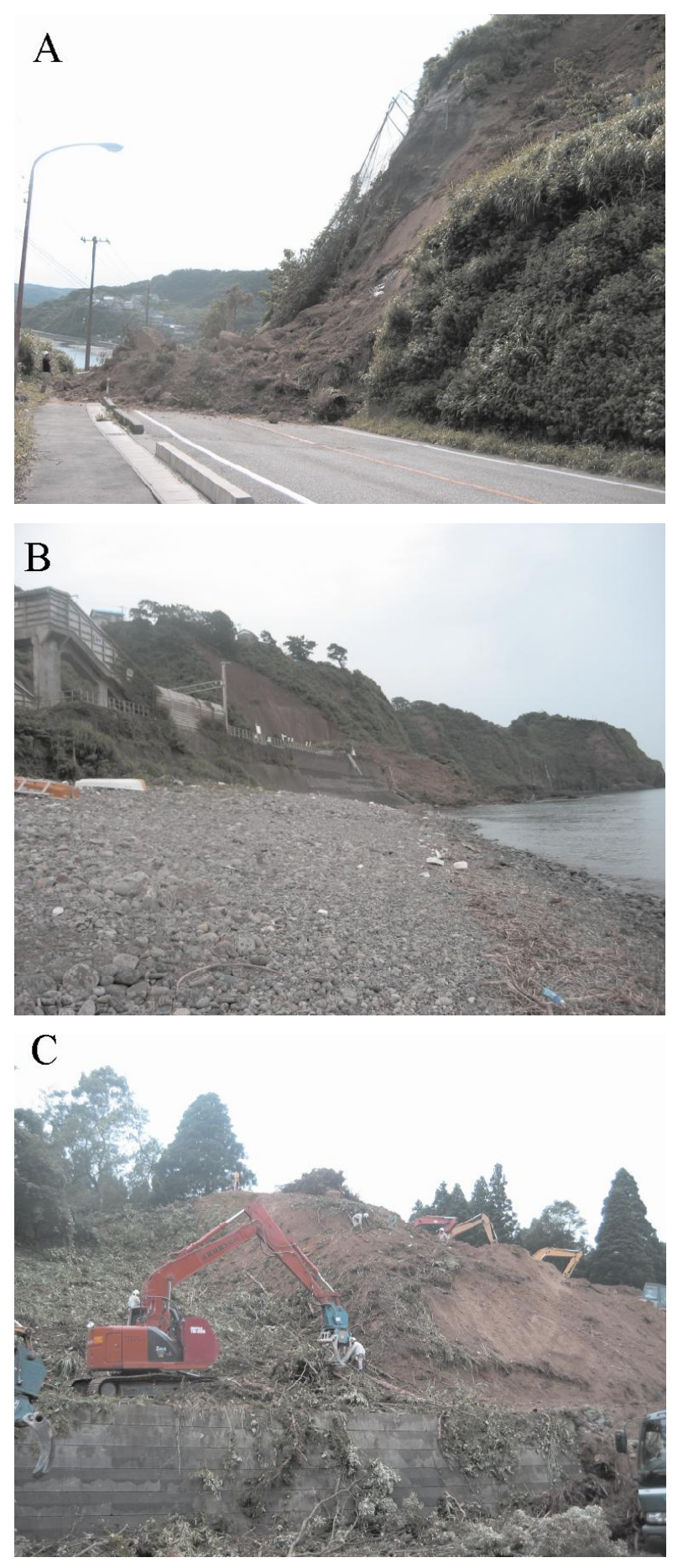

Figure 2. Photos of slope failures triggered by the 2007 Chuetsu-Oki earthquake: Photo A - a shallow slide on National Highway 352; Photo B - the Oumigawa landslide and a few shallow failures in weathered mudstone near the Oumigawa Train Station; Photo C - a view of the Ohzumi landslide. Within one week after the landslide occurred, the landslide mass was quickly removed and the road was re-opened. Locations of A, B, and C are shown on the map in Figure 1. 


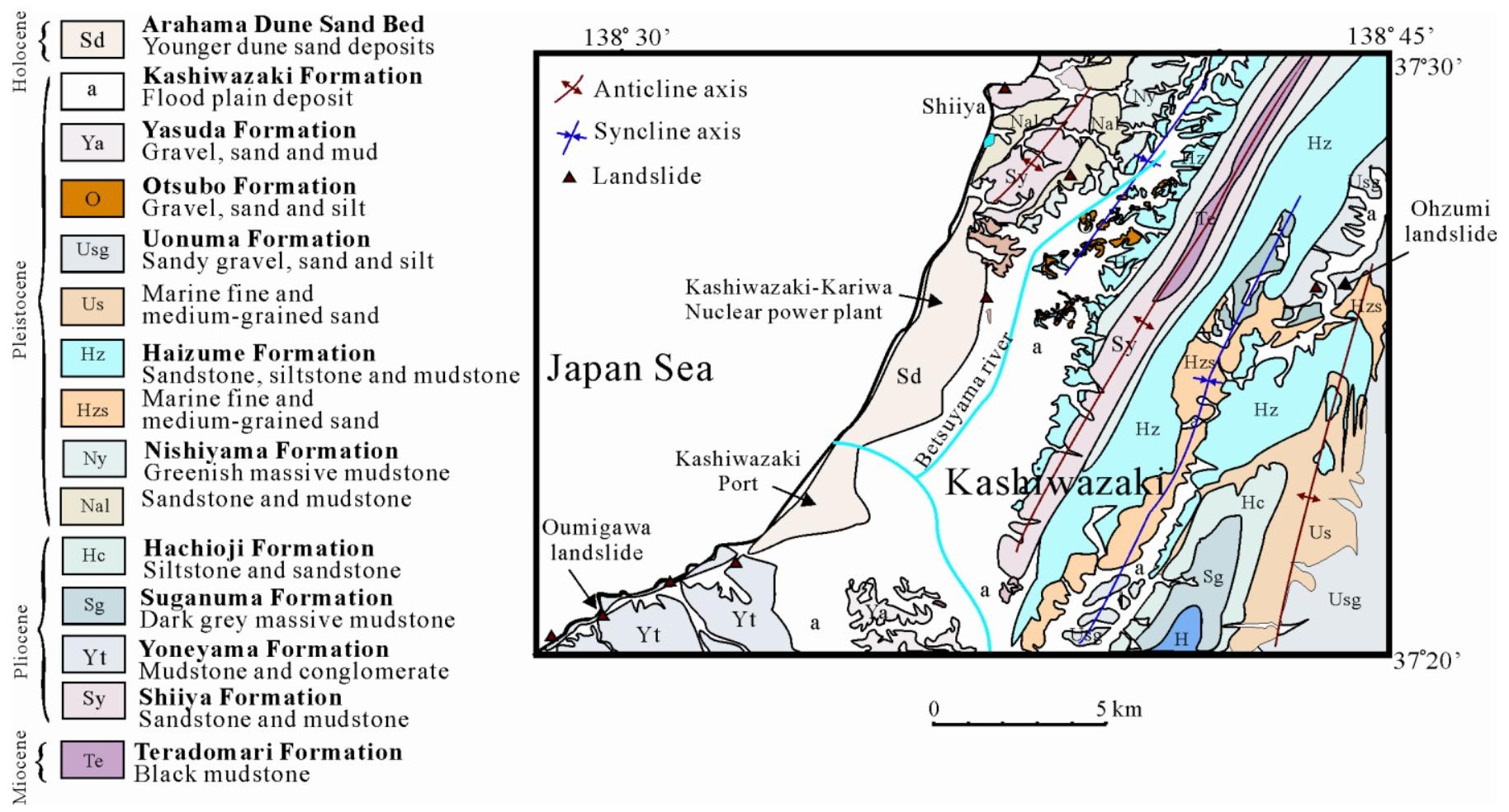

Figure 3. Geologic outline and the distribution of major landslides. Geologic outline is modified from Kobayashi et al. (1995). 

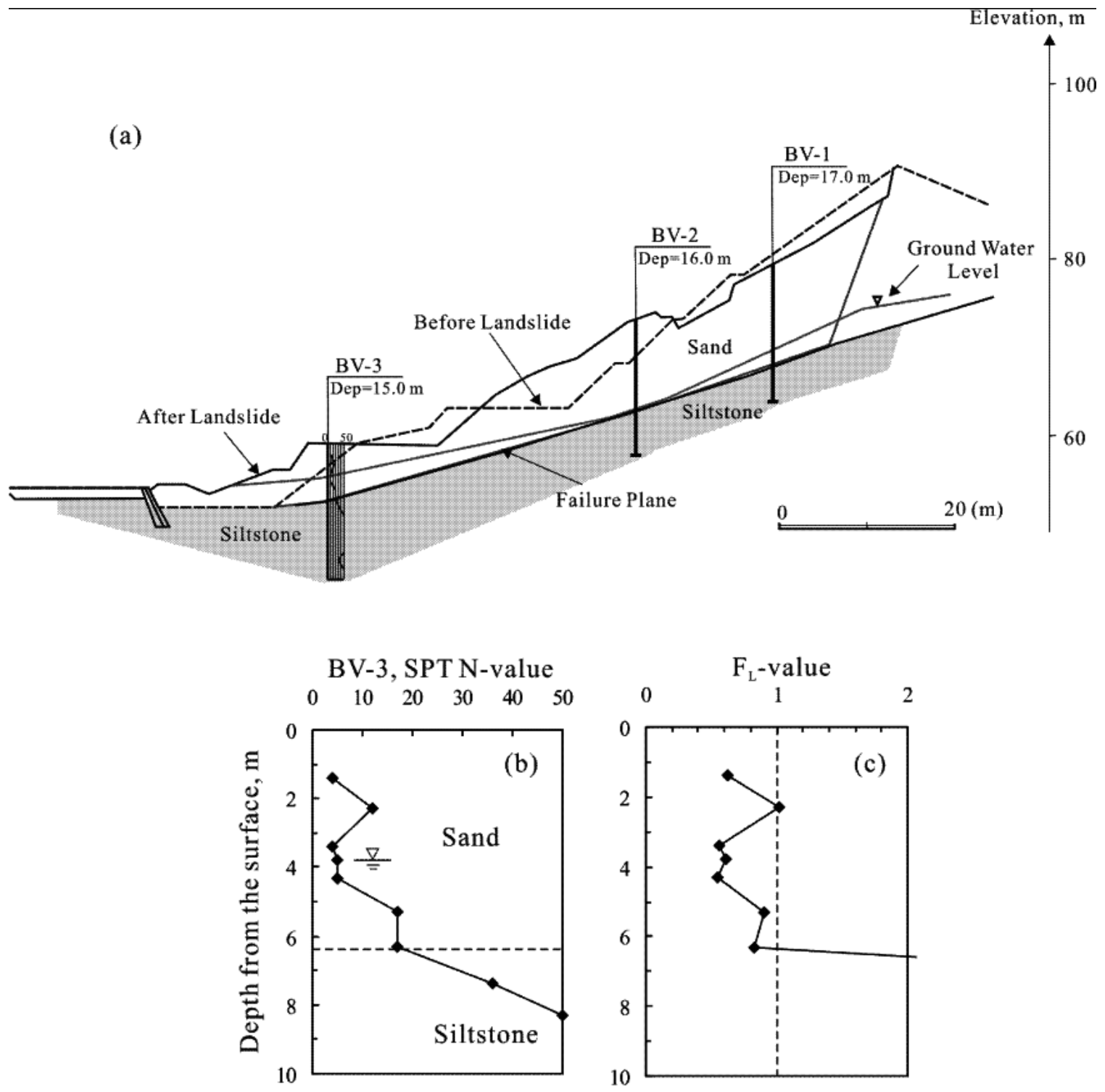

Figure 4. A cross-section of the slope prior to and after the earthquake (a), results of Standard Penetration Test at a borehole BV-3 (b), and results of liquefaction analysis conducted in accord with the 1996 Japan Road Association procedure (c). $F_{L}$ - safety factor against liquefaction. 


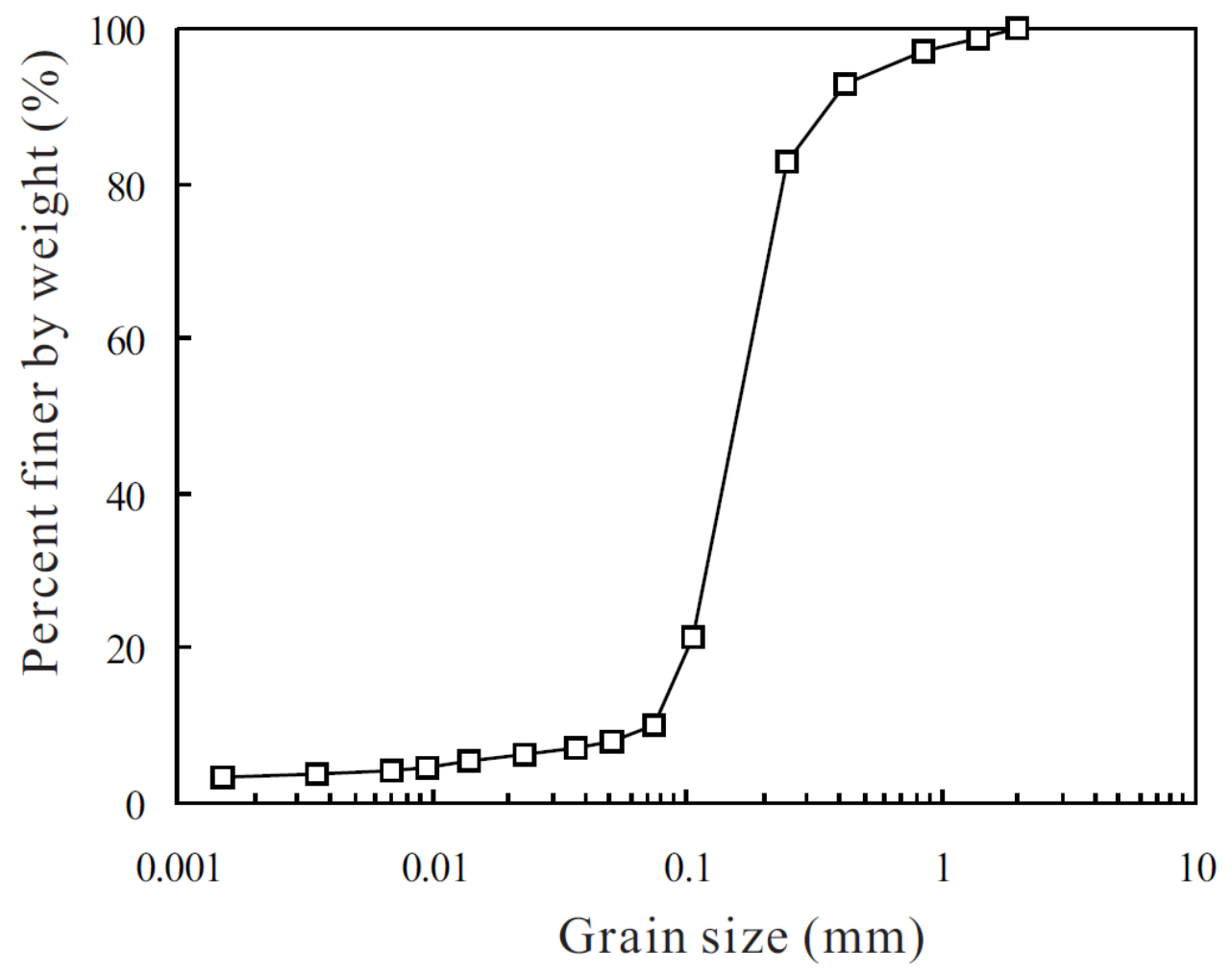

Figure 5. Grain size distribution of the sandy soil from the landslide mass. 

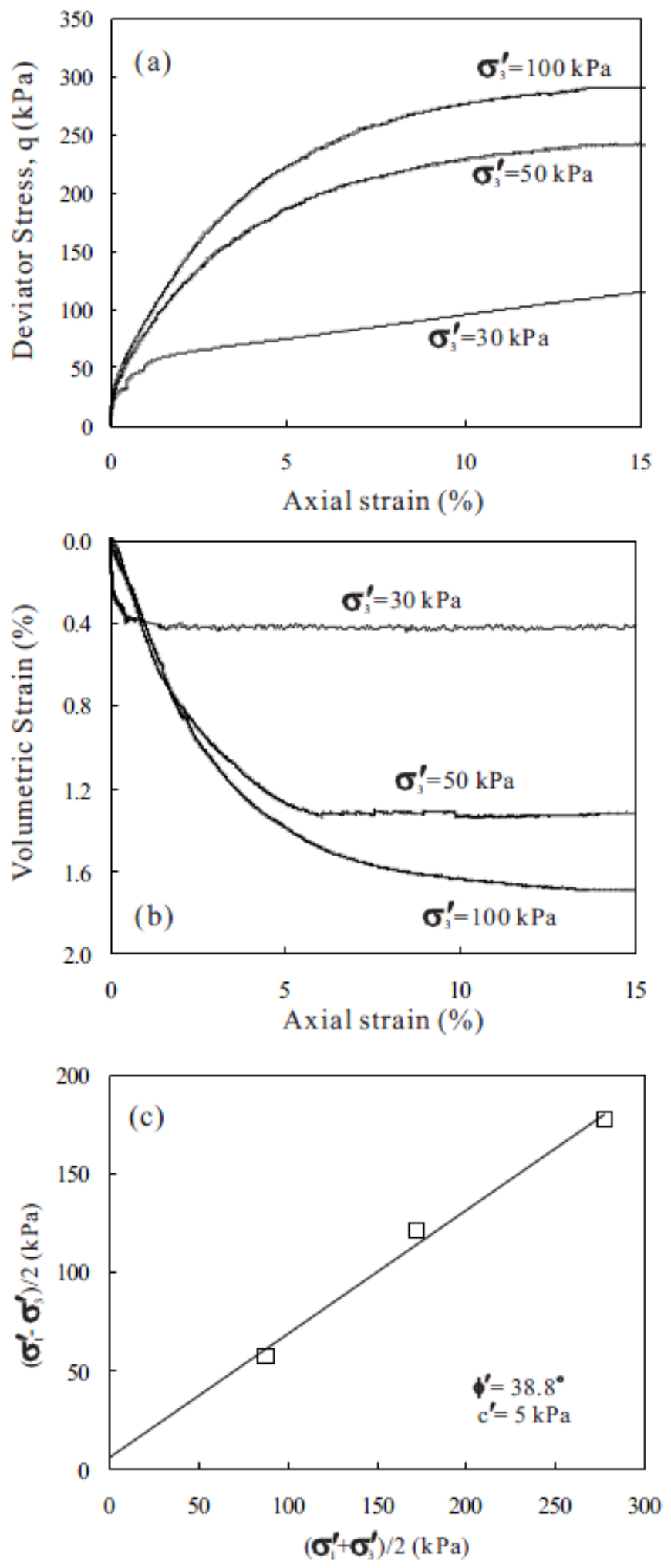

Figure 6. Results of consolidated-drained triaxial compression tests performed at different initial effective confining stresses. (a) Stress-strain relationships, (b) volumetric strain relationship, and (c) effective stress conditions at failure ( $\phi$ ' - friction angle, c' - effective cohesion). 


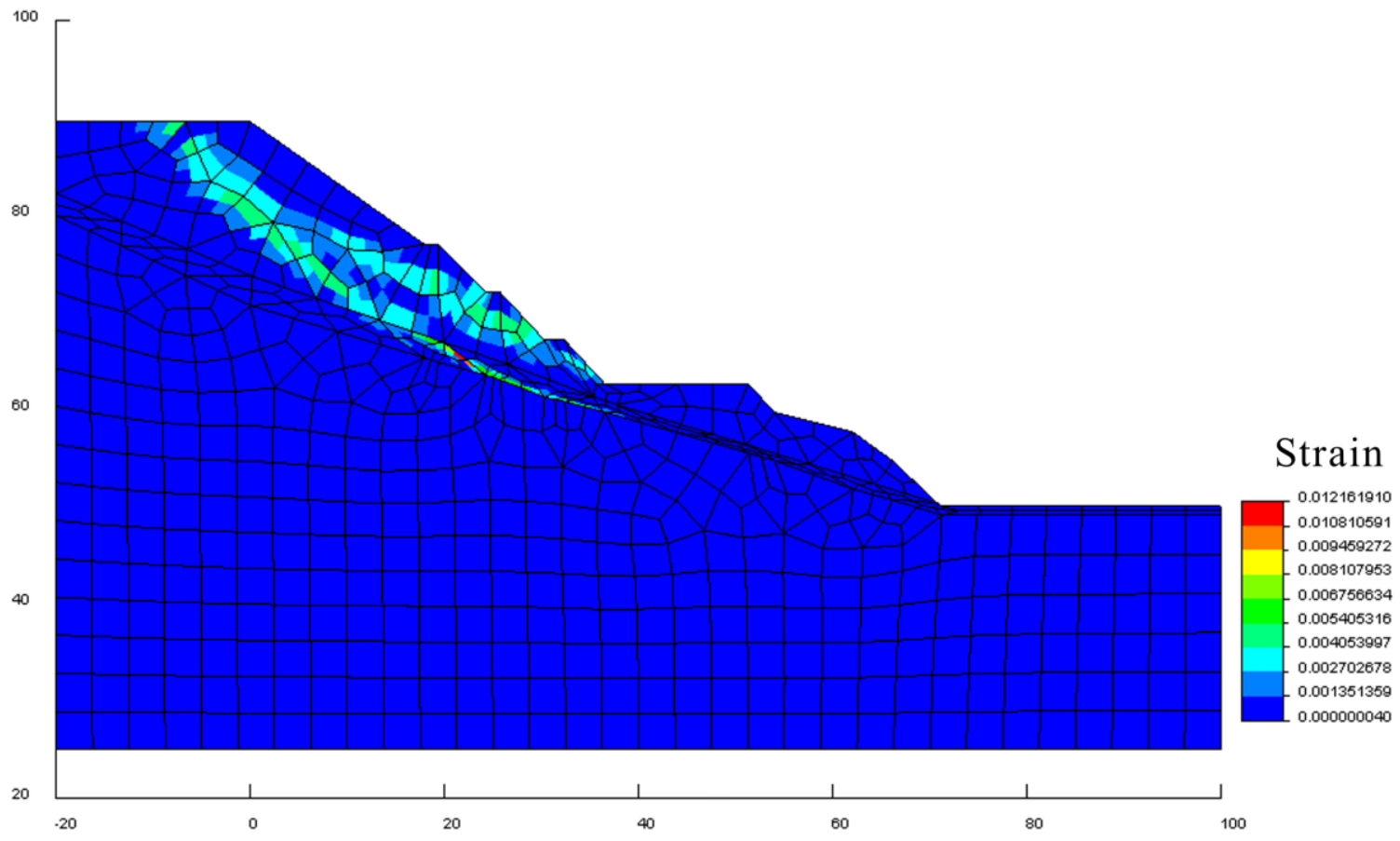

Figure 7. Results of slope stability analysis conducted for the conditions existing before the earthquake. The safety factor was estimated to be 1.34 .

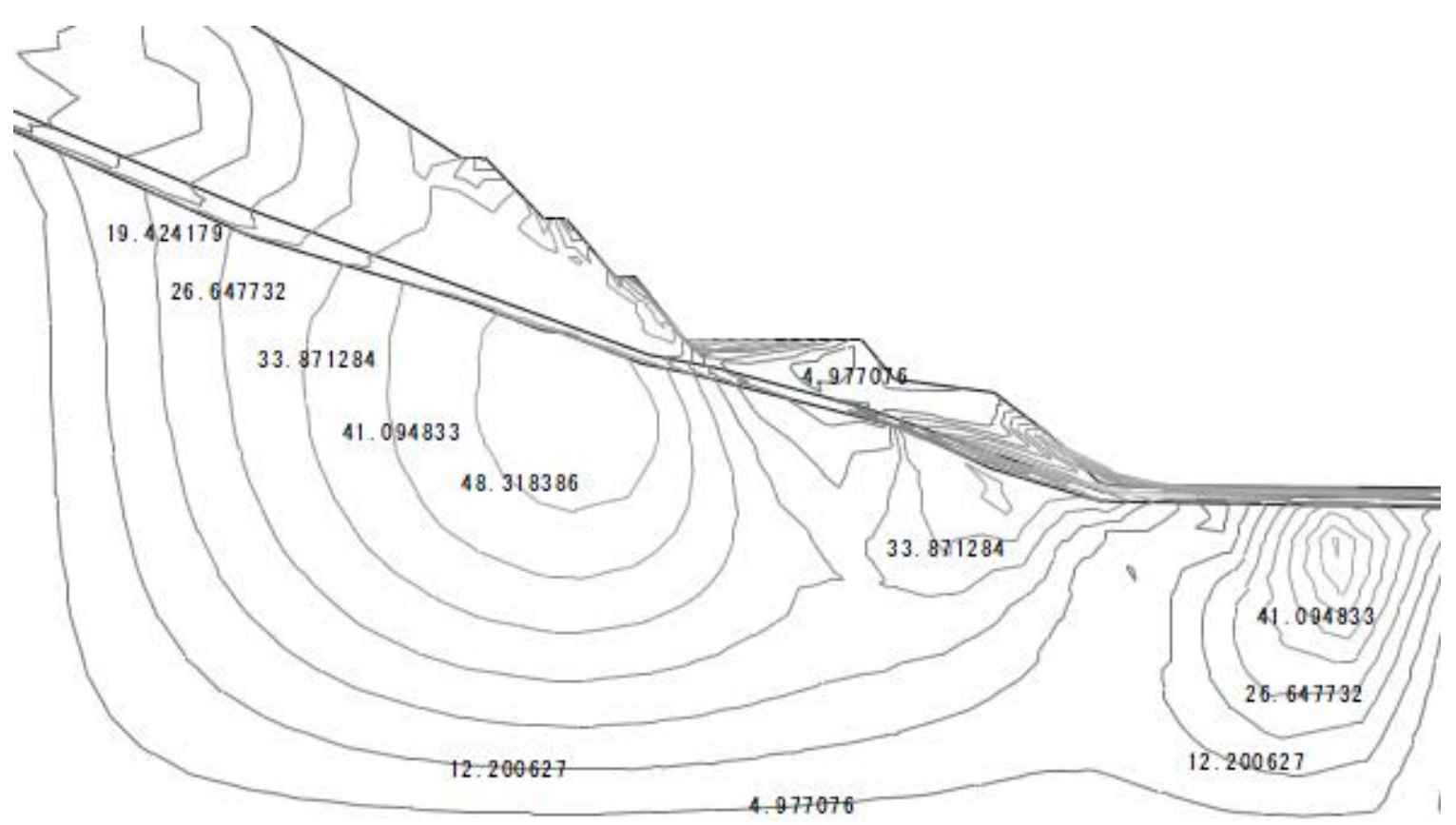

Figure 8. Distribution of shear stresses $(\tau, \mathrm{kPa})$ in the slope before the earthquake calculated by means of the FEM procedure. 

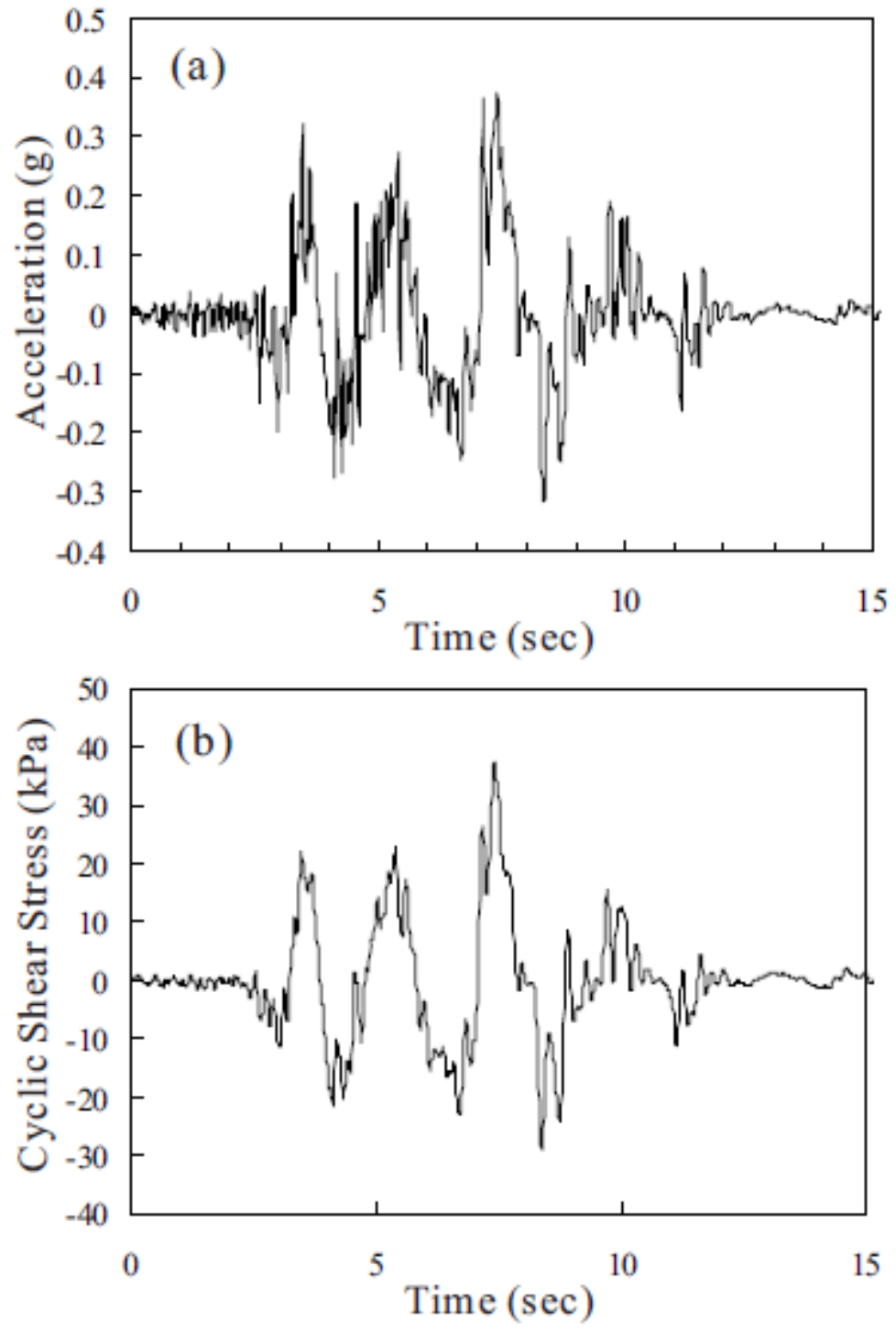

Figure 9. Results of seismic response analysis computed for the depth range of 4-6 m: (a) acceleration, and (b) cyclic shear stress time histories. 

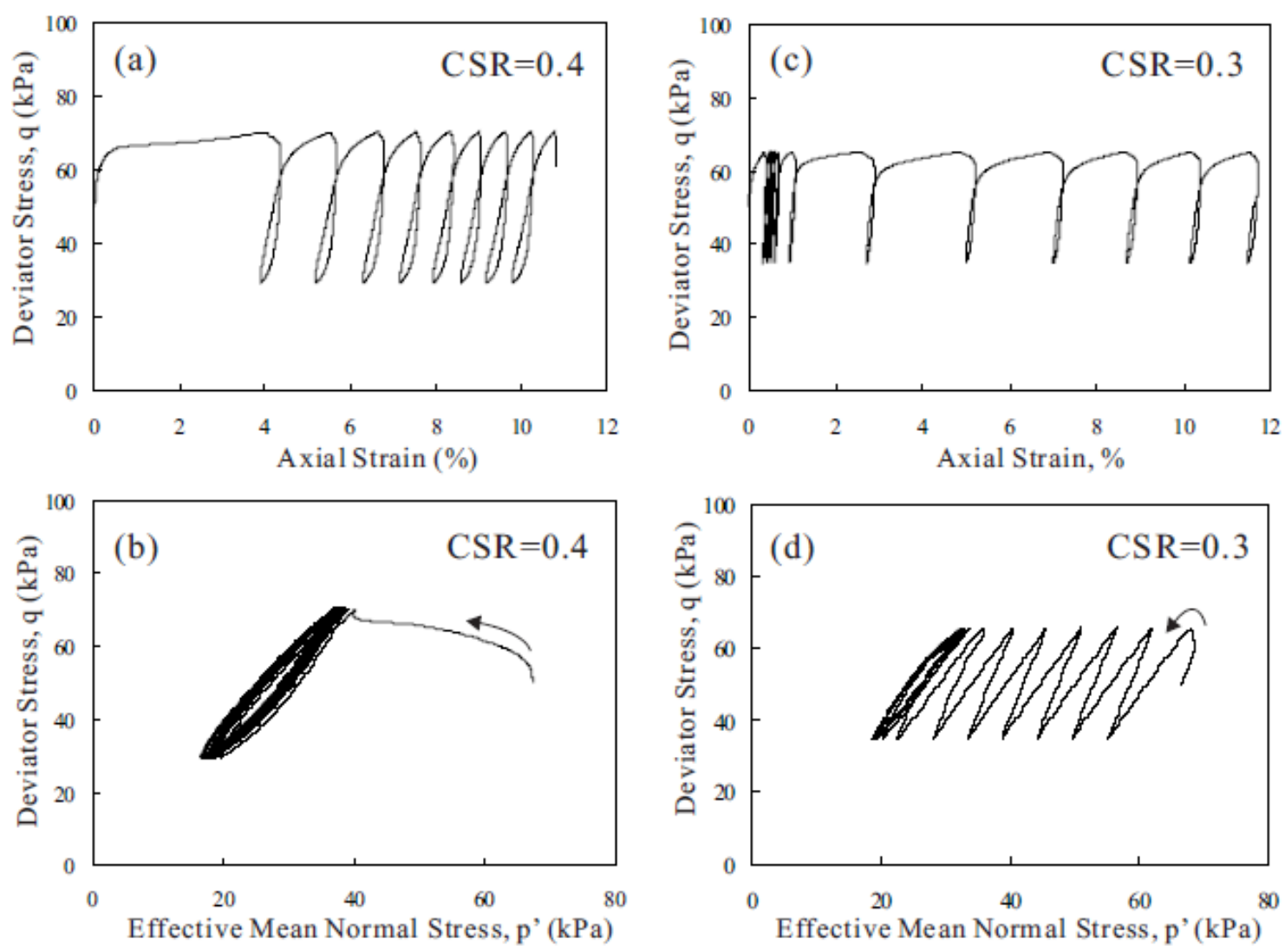

Figure 10. Results of cyclic loading undrained triaxial compression tests plotted as: (a, c) deviator stress versus axial strain; and (b, d) deviator stress versus mean effective confining stress. Relative density $\operatorname{Dr}=41 \%$.

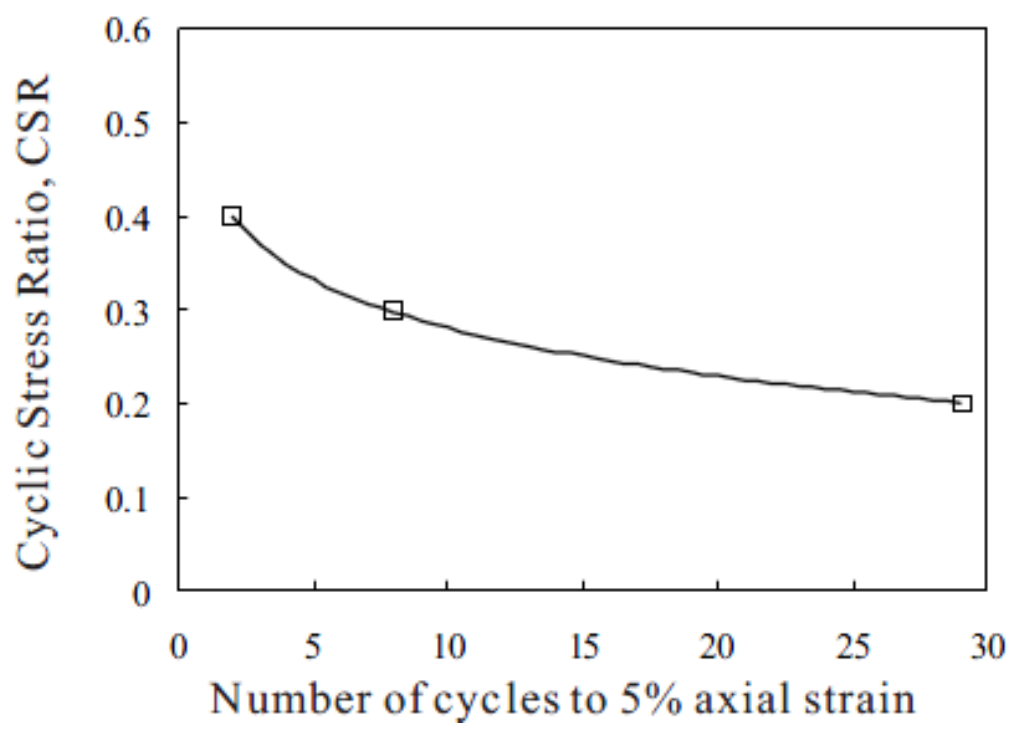

Figure 11. Summary of cyclic loading undrained triaxial compression tests. 


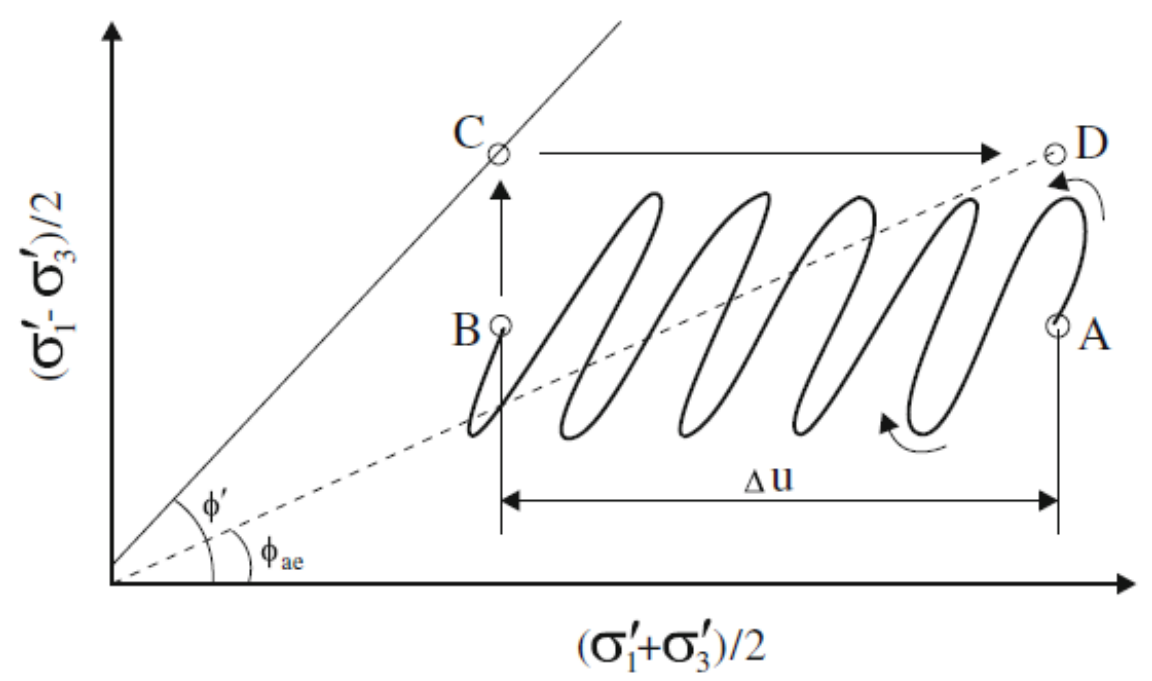

Figure 12. Determination of the post-earthquake strength of the sand on the basis of triaxial tests. $\left(\Delta \mathrm{u}\right.$ - excess pore-water pressure, $\phi '$ - effective friction angle, $\phi_{\mathrm{ae}}-$ friction angle after the earthquake).

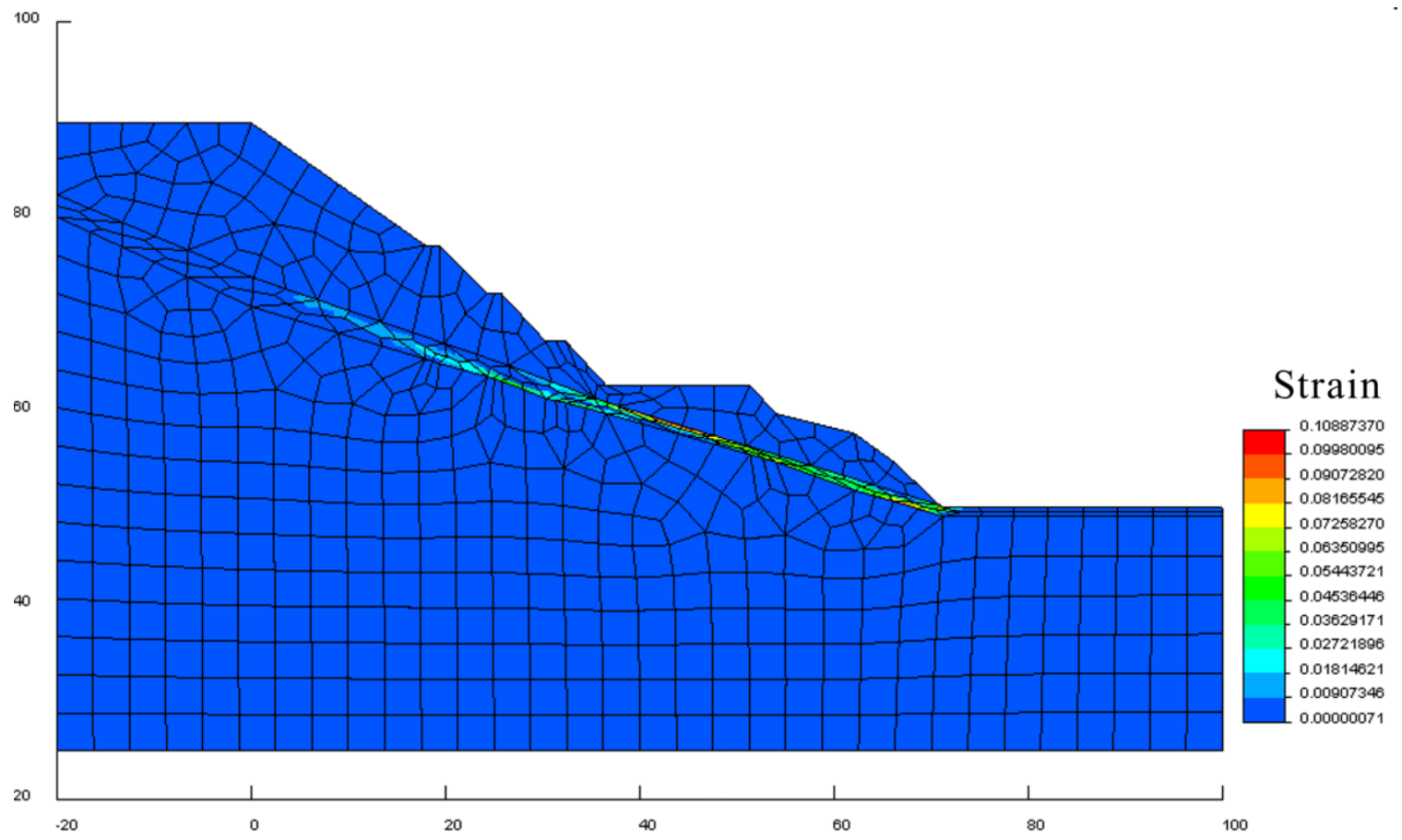

Figure 13. Results of slope stability analysis conducted for the conditions existing after the earthquake. The safety factor was estimated to be 0.58 . 